\title{
Text Mining Literature Review on Indonesian Social Media
}

\author{
Angelina Pramana Thenata ${ }^{\# 1}$

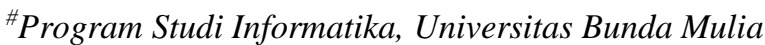 \\ Jl. Jalur Sutera Barat Kav. 7-9, Tangerang, 15143, Indonesia \\ ${ }^{1}$ angelina.pramana31@gmail.com
}

\begin{abstract}
Abstrak - Era sekarang jumlah berita dari berbagai media sosial yang tersebar dalam waktu singkat dan kebutuhan masyarakat untuk mengkonsumsi berita dalam berbagai referensi dapat mempengaruhi kehidupan masyarakat. Hal ini menyebabkan data yang tersebar dapat dikumpulkan dan dimanfaatkan oleh pemerintah, pengusaha, analisis, ataupun peneliti untuk mengidentifikasi tren, mengembangkan bisnis, memprediksi perilaku pelanggan dan lain sebagainya. Pengumpulan data berita dari media sosial tersebut dapat menggunakan text mining yang melibatkan algoritma yakni Naive Bayes, K-NN, dan SVM. Namun, penggunaan algoritma pada studi kasus yang tidak sesuai dapat memberikan hasil yang tidak optimal. Oleh karena itu, penelitian ini akan menganalisis algoritma text mining yang diimplementasikan pada media sosial berbahasa Indonesia dengan memakai metode systematic literature review. Metode ini dimulai dengan melakukan tahap planning yang menetapkan pertanyaan penelitian, kata pencarian, sumber literatur digital, dan standard literatur. Dilanjutkan dengan tahap conducting yang memilih dan mencocokan standard literatur, serta ekstraksi data. Kemudian tahap reporting yang melakukan analisis hasil ekstraksi data sehingga bisa menemumkan informasi dan pengetahuan. Tolak ukur yang menjadi acuan untuk perbandingan yakni pengujian confusion matrix berupa accuracy, precision, dan recall. Adapun hasil dari penelitian ini ditemukan algoritma Naive Bayes memberikan hasil yang stabil tapi kurang optimal jika diterapkan pada studi kasus media sosial berbahasa Indonesia. Sedangkan algortima K-NN dan SVM ditemukan memberikan hasil yang optimal jika diterapkan pada studi kasus media sosial berbahasa Indonesia yang dibuktikan dengan accuracy $(50 \%-98.13 \%)$, precision $(58.22 \%-98.48 \%)$, dan recall (21.05\%-98\%).
\end{abstract}

Kata kunci- Media Sosial, Text Mining, Literature Review, Naive Bayes, K-NN, SVM

\section{Pendahuluan}

Tahun 2021 negara Indonesia menempati peringkat ketiga dalam Asia Pasifik yang memiliki pengguna internet sebanyak 202,6 juta. Diantaranya sebesar 61,8\% masyarakat Indonesia adalah pengguna aktif media sosial [1]. Hal ini membuat data dalam jumlah yang besar beredar secara online baik gratis maupun berbayar. Salah satu data yang setiap saat beredar adalah berita dari media sosial yang menyajikan peristiwa, kejadian ataupun opini dari berbagai bidang baik ekonomi, politik, teknologi, lifestyle, dan lain-lain. Media sosial ini menarik perhatian pembaca dengan memberikan kemudahan dan kecepatan dalam menyajikan berita terkini. Jumlah berita dari berbagai media sosial yang tersebar dalam waktu singkat dan kebutuhan masyarakat untuk mengkonsumsi berita dalam berbagai referensi dapat mempengaruhi kehidupan masyarakat.

Analisis data yang berasal dari berbagai sumber media sosial sangat penting untuk membantu pengambilan keputusan yang efektif [2]. Hasil analisis data tersebut dapat digunakan untuk mengidentifikasi tren, mengembangkan bisnis, peluang, memprediksi perilaku pelanggan dan pergeseran pasar, investigasi kejahatan, dan risiko bencana alam. Penemuan pengetahuan ini melibatkan algoritma yang dapat diterapkan pada text mining yakni Naive Bayes, K-NN, dan SVM [3]. Namun, jika penggunaan algoritma ini tidak diterapkan pada studi kasus yang sesuai dapat memberikan hasil yang tidak optimal bahkan dapat menyesatkan [4]. Oleh sebab itu, peneliti akan menganalisis algoritma text mining yang diimplementasikan pada media sosial berbahasa indonesia. Faktor yang akan dianalisis yakni pengujian confusion matrix yang dapat berupa accuracy, precision, dan recall. Adapun, hasil penelitian ini nantinya dapat bermanfaat bagi perusahaan media massa, peneliti ataupun analis untuk mendapatkan informasi dan pengetahuan, serta mendapatkan insight yang berharga.

\section{TINAJUAN PUSTAKA}

\section{A. Text Mining}

Penemuan pengetahuan yang menarik pada dokumen teks dapat menggunakan text mining. Text mining dapat mengolah data yang berbentuk semi struktur dan tidak terstruktur [5]. Adapun, tata cara untuk melakukan text mining secara berurut ditunjukkan pada Gambar 1 .

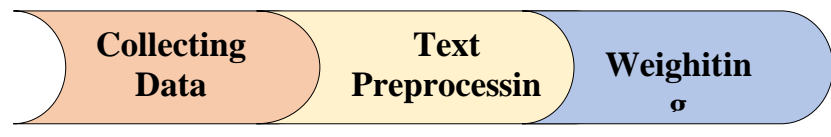

Gambar 1. Tahapan text mining [6] 
Gambar 1 menunjukan proses pertama yang perlu dilakukan dalam text mining yakni pengumpulan data (collecting data) pada media sosial dapat berasal dari twitter, facebook, instagram, dan lain sebagainya dengan mencari kata kunci (keyword) tertentu, seperti Gambar 2 yang menunjukkan sampel pengumpulan data pada twitter yang mengumpulkan keyword "Covid-19".

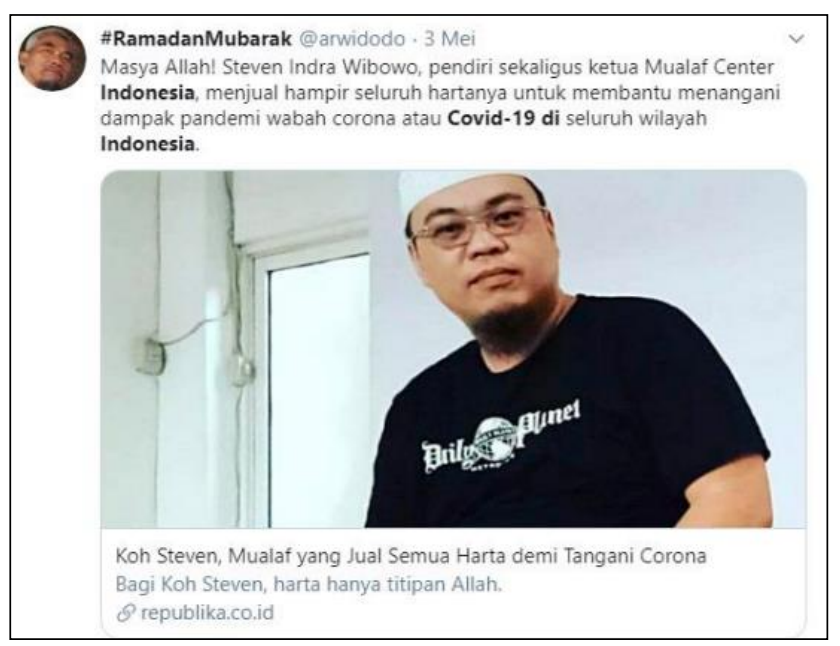

Gambar 2. Pengumpulan data [7]

Setelah mengumpulkan data, dilakukan tahap text preprocessing yang berfungsi untuk menyiapkan data siap pakai agar mudah untuk dianalisis. Langkah-langkah dalam text preprocessing dapat dilihat pada Gambar 3.

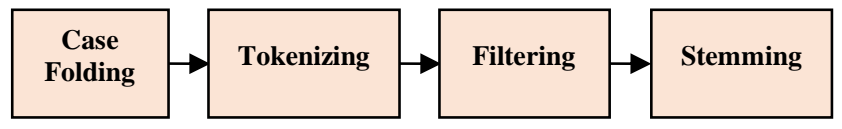

Gambar 3. Tahap text preprocessing [8]

Proses pertama dalam text preprocessing adalah case folding, seperti "Ternyata" menjadi "ternyata" dan simbol dihapus atau dianggap delimiter. Kemudian dilakukan tokenizing yakni pemotongan string text input menjadi satuan kata. Selanjutnya dilakukan filtering yakni pengambilan kata-kata penting (wordlist), dan pembuangan kata kurang penting (stopword), serta filter bahasa asing menjadi Bahasa Indonesia dari hasil tokenizing. Contoh stopword dalam Bahasa Indonesia yakni "yang”, "dan”, "di”, dan lain sebagainya. Kemudian dilakukan stemming yakni pengkelompokkan kata dasar dalam Bahasa Indonesia, serta kata imbuhan seperti sufix dan prefiks dihilangkan [9].

Setelah tahap preprocessing dilanjutkan ke tahap pembobotan kata (weighting). Tahap ini perlu dilakukan karena setiap kata dalam suatu kalimat memiliki keperluan yang berbeda-beda [10]. Perhitungan rumus untuk menentukan bobot Term Frequency-Inverse Document Frequency (TF-IDF) dinyatakan dengan persamaan (1) dan (2).

$$
w_{i j}=t f_{i j} \times i d f_{j}
$$

$$
w_{i j}=t f_{i j} \times \log \frac{D}{d f_{j}}
$$

Dengan $w_{i j}$ merupakan pembobotan TF-IDF, kemudian tf merupakan banyaknya kata yang muncul, dan $d f$ sebagai frekuensi muncul kata dalam satu dokumen, serta $D$ sebagai banyaknya dokumen [11]. Berdasarkan karakteristik data hasil pengolahan teks tersebut terdapat 3 algoritma populer yang dapat digunakan untuk text mining. Algoritma pertama yakni Naive Bayes yang memanfaatkan probabilitas dan statistika dalam bentuk sederhana. Algoritma kedua yakni SVM yang merupakan metode yang lebih matang untuk mengenali pola untuk klasifikasi dan dianggap memiliki akurasinya yang baik dalam klasifikasi teks. Algoritma ketiga yakni K-NN yang merupakan metode klasifikasi data sederhana yang mengklasifikasikan data berdasarkan kedekatan data dengan data lain. Akhirnya, hasil data text preprocessing akan dianalisis menggunakan ketiga algoritma populer tersebut.

\section{B. Naive Bayes}

Thomas Bayes menemukan Naive Bayes di abad ke-18. Algoritma ini didasari oleh teorema bayes yang menggunakan perhitungan berupa probablitias dan statistik untuk menyelesaikan berbagai masalah dalam machine learning.

$P(A \mid B)=\frac{P(B \mid A) P(A)}{P(B)}$

Persamaan (3) memiliki komponen B yang merupakan data dari suatu dataset yang belum diketahui kelasnya. A merupakan peluang yang akan menentukan B tergolong ke suatu kelompok tertentu. Komponen $\mathrm{P}(\mathrm{A} \mid \mathrm{B})$ adalah hasil probabilitas posterior berdasakan kondisi X. Sebaliknya $\mathrm{P}(\mathrm{B} \mid \mathrm{A})$ merupakan probabilitas berdasarkan kondisi A. Kemudian $\mathrm{P}(\mathrm{A})$ merupakan probabilitas prior atau probablitas hipotesis. Sedangkan $\mathrm{P}(\mathrm{B})$ merupakan probabilitas B [12].

\section{SVM}

Boser, Guyon, dan Vapink mengembakan algoritma SVM (Support Vector Machine). Algoritma tersebut dapat melakukan pengenalan pola dan analisis data. SVM bekerja pada permasalahan non linear ataupun linear sehingga nantinya dapat menemukan fungsi pemisah (hyperlane) terbaik diantara fungsi yang tidak terbatas jumlahnya. Hyperlane paling optimum dapat ditemukan dengan menggunakan persamaan (4)

dengan subject to:

$$
\min \frac{1}{2}\|\omega\|^{2}
$$

$y_{i}\left(w x_{i}+b\right) \geq 1, i=1, \ldots, \lambda$

Dimana $x_{i}$ merupakan data masukkan, dan $y_{i}$ merupakan output dari $x_{i}$, serta $\omega$ merupakan paramater klasifikasi [13].

D. $K-N N$

K-NN (K-Nearest Neighbor) adalah algoritma sederhana yang bisa menyelesaikan permasalahan 
klasifikasi baik berupa teks ataupun data lainnya. Adapun K-NN bekerja dengan berlandaskan data yang jaraknya terdekat dengan obyek tertentu. Titik $X_{1}$ dan $X_{2}$ didefinisikan perhitungan jaraknya pada persamaan (5).

$$
d\left(X_{1}, X_{2}\right)=\sqrt{\sum_{j=1}^{p}\left(X_{1 j}-X_{2 j}\right)^{2}}
$$

Dimana $d\left(X_{1}, X_{2}\right)$ sebagai jarak antara variabel X1 dan $X 2$, kemudian $X$ sebagai objek, dan p sebagai jumlah dimensi variabel [14].

\section{Metode PENELITIAN}

Peneliti menggunakan metode sytematic literature review. Metode tersebut digunakan untuk identifikasi, evaluasi, dan integrasikan hasil penemuan dari setiap penelitian yang relevan sehingga dapat memberikan jawaban dari pertanyaan penelitian [15]. Penelitian ini menggunakan studi kasus mengenai algoritma text mining yang diimplementasikan pada media sosial berbahasa indonesia. Adapun, proses systematic literature review yang digunakan pada penelitian ini ditunjukkan dalam Gambar 4.

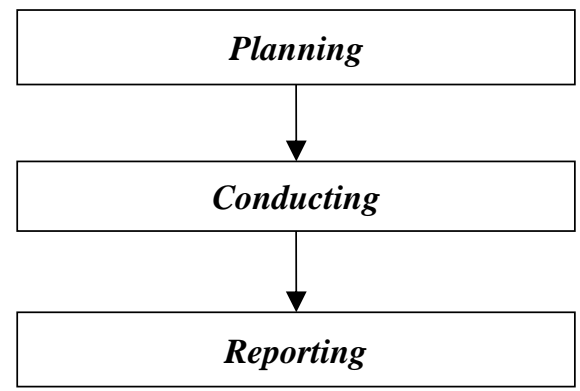

Gambar 4. Tahap penelitian

Pada tahap planning dilakukan penetapan pertanyaan penelitian, kata pencarian, sumber literatur digital, dan standard literatur. Selanjutnya, tahap conducting adalah pemilihan dan pencocokan standard literatur, serta ekstraksi data. Akhirnya, tahap reporting adalah melakukan analisis hasil ekstraksi data sehingga bisa menemumkan informasi dan pengetahuan.

\section{HASIL DAN PEMBAHASAN}

\section{A. Planning}

Langkah pertama dalam tahap perencanaan yang dilakukan yakni menetapkan pertanyaan terhadap penelitian yang dilakukan (research questions) terkait algoritma yang diteliti.

- RQ1: Apa saja elemen confusion matrix yang diterapkan pada pengimplementasian text mining terhadap media sosial berbahasa Indonesia berdasarkan algoritma yang digunakan dalam semua literatur yang diteliti?

- $\quad$ RQ2: Apa saja hasil confusion matrix yang diterapkan pada pengimplementasian text mining terhadap media sosial berbahasa Indonesia berdasarkan algoritma yang digunakan dalam masing-masing literatur yang diteliti?

Selanjutnya, langkah kedua yakni menetapkan kata pencarian untuk mencari literature yang akan diteliti (search strings). Kata pencarian tersebut berkaitan dengan literatur yang akan diteliti yakni "text mining". Kemudian kata pencarian lainnya adalah berbagai algoritma populer yang sering di implementasikan untuk text mining adalah "Naive Bayes", "SVM", dan "K-NN" [16]. Berikutnya kata pencarian yang digunakan terkait dengan implementasi text mining pada "media sosial bahasa Indonesia".

Adapun, kata pencarian ini digunakan agar memperoleh literatur yang mengurai implementasi text mining pada media sosial berbahasa Indonesia yang menggunakan algoritma klasifikasi yakni Naive Bayes, K-NN, dan SVM. Namun, literatur yang membahas text mining pada media sosial berbahasa Indonesia dan tidak menunjukkan pembahasan mengenai hasil penggunaan algoritma berupa confusion matrix tidak diikut sertakan.

Kemudian langkah ketiga yang dilakukan adalah menentukan digital library literatur yang diteliti. Digital library dalam penelitian ini yaitu Google Scholar (GS), IEEE, dan Science Direct (SD).

Terakhir, langkah keempat adalah menentukan kriteria literatur yang diteliti (literature criteria). Kriteria tersebut adalah literatur yang terbit diantara tahun 2015 - 2021 dan membahas mesalah penelitian text mining pada media sosial berbahasa Indonesia. Selain itu, banyaknya literatur dalam penelitian ini minimal 5 literatur diteliti untuk setiap algoritma Naive Bayes, SVM, dan K-NN.

\section{B. Conducting}

Tahap pelaksanaan (conducting) proses systematic literature review yakni melakukan pemilihan dan mencocokan kriteria literatur (exclusion criteria and selection). Kriteria tersebut dalam penelitian ini antara lain:

- Studi penggunaan text mining pada media sosial berbahasa Indonesia

- Jurnal literatur terbit tahun 2010-2021

- Jurnal literatur yang digunakan terbitan nasional ataupun internasional

- Literatur yang memiliki pembahasan mengenai implementasi text mining menggunakan algoritma klasifikasi yakni Naive Bayes, SVM, dan K-NN.

- Literatur yang membahas text mining pada media sosial berbahasa Indonesia, namun tidak menunjukkan hasil penggunaan algoritma berupa confusion matrix tidak diikut sertakan.

Setelah melakukan proses exclusion criteria and selection ditemukan total literatur sebanyak 20 literatur. Hasil temuan literatur tersebut berdasarkan tahun terbitnya ditunjukkan pada Tabel 1. 
TABEL I

HASIL MEMILIH DAN MENCOCOKKAN LITERATUR BERDASARKAN TAHUN TERBIT

\begin{tabular}{|c|c|}
\hline Tahun & Jumlah \\
\hline 2015 & 1 \\
\hline 2017 & 3 \\
\hline 2018 & 1 \\
\hline 2019 & 6 \\
\hline 2020 & 6 \\
\hline 2021 & 3 \\
\hline Total & $\mathbf{2 0}$ \\
\hline
\end{tabular}

Kemudian hasil memilih dan mencocokan berdasarkan algoritma yang diteliti, dan tahun terbitnya ditunjukkan pada Gambar 5, 6, dan 7. Adapun judul literatur yang diteliti dilambangkan dengan huruf " $R$ " dan tahun terbit literatur direpresentasikan dengan warna chart berupa jingga (Naive Bayes), hijau (K-NN), dan kuning (SVM).

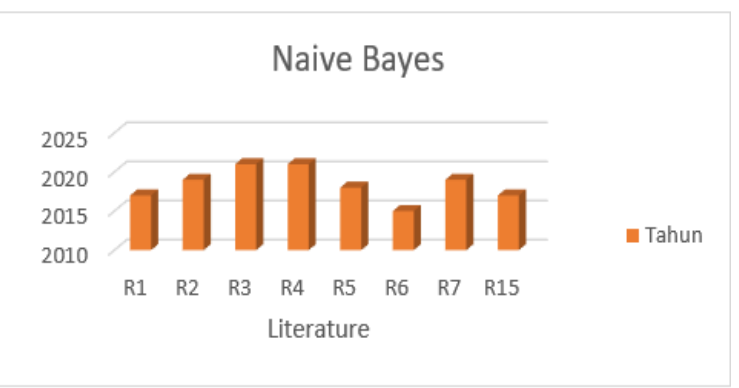

Gambar 5. Hasil distribusi literatur naive bayes

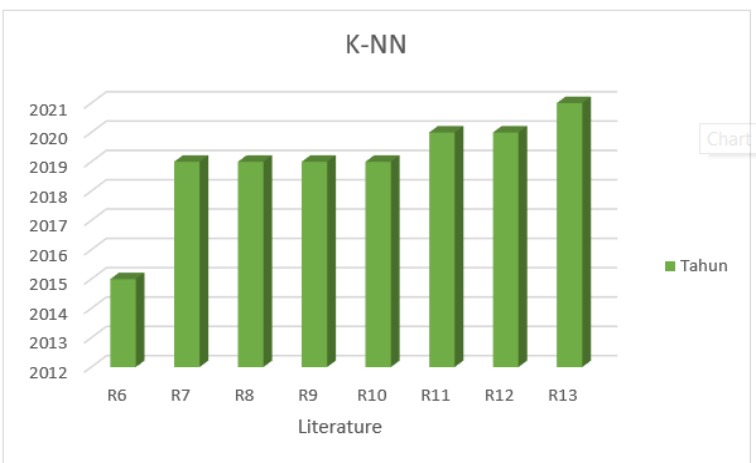

Gambar 6. Hasil distribusi literatur K-NN

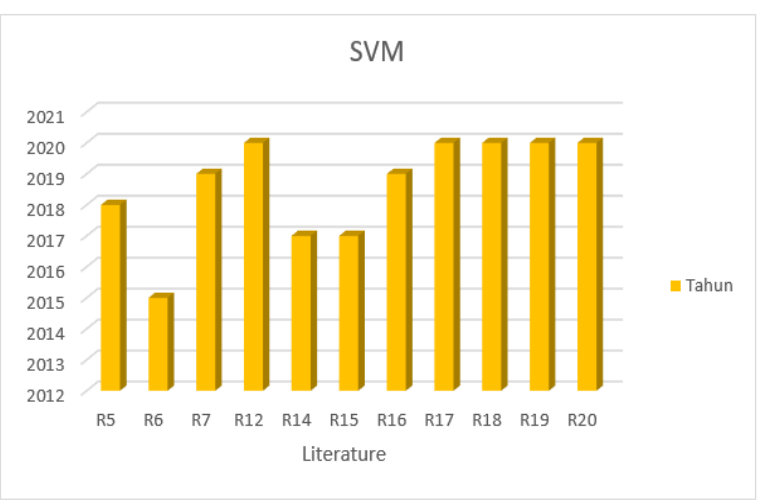

Gambar 7. Hasil distribusi literatur SVM

Gambar 5 menunjukkan literatur Naive Bayes yang diteliti adalah literatur terbitan tahun 2015-2021[16]-[23].
Kemudian Gambar 6 menunjukkan literatur Naive K-NN yang diteliti adalah literatur terbitan tahun 2015-2021 [14], [16], [22], [24]-[28]. Berikutnya, Gambar 7 menunjukkan literatur SVM yang diteliti adalah literatur terbitan tahun 2015-2020 [16], [21]-[23], [27], [29]-[34].

Selanjutnya dari hasil temuan literatur tersebut dilakukan ekstraksi data yang bertujuan untuk menjawab pertanyaan penetilian. Pertanyaan penelitian yang telah ditentukan pada tahap planning adalah RQ1 dan RQ2 yang dimana mempunyai keserupaan tentang implementasi text mining pada media sosial berbahasa Indonesia.

Hasil ekstraksi data dari semua literatur ditemukan jawaban untuk research question 1 (RQ1) yakni elemen confusion matrix yang diterapkan dalam semua literatur yang diteliti telah dipaparkan sebagai berikut.

1) Accuracy: menggambarkan tingkat kedekatan nilai hasil klasifikasi dengan nilai sebenarnya sehingga dapat diketahui tingkat akurasi dari model yang melakukan klasifikasi dengan benar. Adapun nilai akurasi ini didapatkan dengan menggunakan persamaan (6). Persamaan ini melakukan perbandingan prediksi benar dengan keseluruhan data.

$$
\text { Accuracy }=\frac{T P+T N}{T P+T N+F P+F N}
$$

Persamaan accuracy memliki komponen true positive (TP) sebagai banyaknya data prediksi benar positif sama dengan data aktualnya, dan komponen true negatif (TN) sebagai banyaknya data prediksi benar negatif sama dengan data aktualnya. Sebaliknya komponen false postive (FP) sebagai banyaknya data prediksi salah posiitif tidak sama dengan data aktualnya, dan FN (False Negative) merupakan jumlah data prediksi salah negatif tidak sama dengan data aktualnya [18].

2) Precision: memaparkan kesesuaian antar data benar positif dengan data prediksi. Adapun precision ini didapatkan dengan menggunakan persamaan (7). Persamaan ini melakukan perbandingan hasil klasifikasi benar positif dengan keseluruhan hasil klasifikasi positif [19].

$$
\text { Precision }=\frac{T P}{T P+F P}
$$

3) Recall: memaparkan keberhasilan klasifikasi dalam memperoleh informasi dari semua data yang tersedia. Nilai recall ini diperoleh dengan menggunakan persamaan (8). Persamaan ini melakukan perbandingan hasil klasifikasi benar positif dengan keseluruhan data [20].

$$
\text { Recall }=\frac{T P}{T P+F N}
$$

Selanjutnya, ditemukan jawaban untuk research question 2 (RQ2) yang dipaparkan dalam Tabel 2, 3, 4, 5, 6, dan 7. Pada Tabel 2, 3, dan 4 menunjukkan elemen confusion matrix yang dominan diterapkan dalam setiap literatur dengan mengimplementasikan algoritma Naive Bayes, algoritma SVM, dan algoritma K-NN. 
TABEL II

ElEMEN CONFUSION MATRIX PADA AlgORITMA NAÏVE BAYES

\begin{tabular}{|l|c|c|c|}
\hline Literature & Accuracy & Precision & Recall \\
\hline R1 & $\times$ & & \\
\hline R2 & $\times$ & $\times$ & $\times$ \\
\hline R3 & $\times$ & $\times$ & $\times$ \\
\hline R4 & $\times$ & $\times$ & $\times$ \\
\hline R5 & $\times$ & & \\
\hline R6 & $\times$ & & \\
\hline R7 & $\times$ & $\times$ & $\times$ \\
\hline R15 & $\times$ & & \\
\hline Total & 8 & 4 & 4 \\
\hline
\end{tabular}

TABEL III

ELEMEN CONFUSION MATRIX PADA ALGORITMA K-NEAREST NEIGBOR

\begin{tabular}{|l|c|c|c|}
\hline Literature & Accuracy & Precision & Recall \\
\hline R6 & $\times$ & & \\
\hline R7 & $\times$ & $\times$ & $\times$ \\
\hline R8 & $\times$ & $\times$ & $\times$ \\
\hline R9 & $\times$ & & \\
\hline R10 & $\times$ & $\times$ & $\times$ \\
\hline R11 & $\times$ & $\times$ & $\times$ \\
\hline R12 & $\times$ & & \\
\hline R13 & $\times$ & $\times$ & $\times$ \\
\hline Total & 8 & 5 & 5 \\
\hline
\end{tabular}

TABEL IV

ELEMEN CONFUSION MATRIX PADA ALGORITMA SUPPORT VECTOR MACHINE

\begin{tabular}{|l|c|c|c|}
\hline Literature & Accuracy & Precision & Recall \\
\hline R5 & $\times$ & & \\
\hline R6 & $\times$ & & \\
\hline R7 & $\times$ & $\times$ & $\times$ \\
\hline R12 & $\times$ & & \\
\hline R14 & $\times$ & & \\
\hline R15 & $\times$ & & \\
\hline R16 & $\times$ & & \\
\hline R17 & $\times$ & & \\
\hline R18 & $\times$ & $\times$ & $\times$ \\
\hline R19 & $\times$ & & \\
\hline R20 & $\times$ & $\times$ & $\times$ \\
\hline Total & 11 & 3 & 3 \\
\hline
\end{tabular}

Adapun Tabel 5, 6, dan 7 menunjukkan hasil confusion matrix dari setiap literatur yang mengimplementasikan algoritma Naive Bayes, algoritma SVM, dan algoritma KNN.

TABEL V

Hasil CONFUSION MATRIX MENGGUNAKAN AlgORITMA NAIVE BAYES

\begin{tabular}{|l|c|c|c|}
\hline Literature & Accuracy & Precision & Recall \\
\hline R1 & $93 \%$ & - & - \\
\hline R2 & $83,43 \%$ & $56 \%$ & $65 \%$ \\
\hline R3 & $88 \%$ & $87 \%$ & $88 \%$ \\
\hline R4 & $84.54 \%$ & $85 \%$ & $85 \%$ \\
\hline R5 & $94 \%$ & - & - \\
\hline R6 & $63 \%$ & - & - \\
\hline R7 & $47.60 \%$ & $12.87 \%$ & $76.83 \%$ \\
\hline R15 & $92.78 \%$ & - & - \\
\hline
\end{tabular}

TABEL VI

HASIL CONFUSION MATRIX MENGGUNAKAN ALGORITMA $K$-NEAREST NEIGBOR

\begin{tabular}{|l|c|c|c|}
\hline Literature & Accuracy & Precision & Recall \\
\hline R6 & $60 \%$ & - & - \\
\hline R7 & $96.32 \%$ & $58.22 \%$ & $21.05 \%$ \\
\hline R8 & $98.13 \%$ & $98 \%$ & $98 \%$ \\
\hline R9 & $50 \%$ & - & - \\
\hline R10 & $79.45 \%$ & $85,85 \%$ & $80.67 \%$ \\
\hline R11 & $87.41 \%$ & $87,36 \%$ & $87,85 \%$ \\
\hline R12 & $61.3 \%$ & - & - \\
\hline R13 & $60.12 \%$ & $92.73 \%$ & $46.77 \%$ \\
\hline
\end{tabular}

TABEL VII

HASIL CONFUSION MATRIX DENGAN ALGORITMA SVM

\begin{tabular}{|l|c|c|c|}
\hline Literature & Accuracy & Precision & Recall \\
\hline R5 & $75.50 \%$ & - & - \\
\hline R6 & $61 \%$ & - & - \\
\hline R7 & $93.34 \%$ & $98.48 \%$ & $8.61 \%$ \\
\hline R12 & $69.27 \%$ & - & - \\
\hline R14 & $79.41 \%$ & - & - \\
\hline R15 & $87.60 \%$ & - & - \\
\hline R16 & $70 \%$ & - & - \\
\hline R17 & $91.8 \%$ & - & - \\
\hline R18 & $86 \%$ & $93.20 \%$ & $91.11 \%$ \\
\hline R19 & $83.33 \%$ & - & - \\
\hline R20 & $96.61 \%$ & $96.70 \%$ & $96.58 \%$ \\
\hline \multicolumn{5}{|r}{}
\end{tabular}

\section{Reporting}

Semua data yang ditunjukkan pada Tabel 2, 3, dan 4 menjabarkan algoritma Naive Bayes, K-NN, dan SVM dominan menggunakan pengujian accuracy untuk mengukur keberhasilan implementasi text mining media sosial berbahasa Indonesia, dan umumnya beberapa peneliti lain juga melakukan pengujian precision dan recall secara bersamaan. Selain itu, ditemukan text mining yang menggunakan algoritma Naive Bayes pada media sosial berbahasa Indonesia dapat menghasilkan tingkat accuracy sekitar $47.60 \%$ - 94\%, precision sekitar $12.87 \%$ - 87\% dan recall sekitar $65 \%$ - $88 \%$. Hasil tersebut dapat dikatakan memberikan hasil yang stabil pada pengolahan text mining media sosial berbahasa Indonesia. Hal ini dikarenakan algoritma Naive Bayes mudah untuk diterapkan, pemrosesan cepat dilakukan sebab menggunakan probabilitas dan statistika yang sederhana namun memberikan hasil yang baik [20]. Adapun penelitian yang dilakukan oleh Ade Clinton Sitepu, dkk algoritma Naive Bayes memiliki kecepatan pemrosesan yang cepat dengan waktu pemrosesan 0.0338492393 dan tetap memberikan precision (87\%), recall (88\%) dan accuracy (88\%) yang tinggi [19].

Sedangkan text mining yang menggunakan algoritma SVM pada media sosial berbahasa Indonesia dapat menghasilkan tingkat accuracy sekitar 61\% - 96.61\%, precision $93.20 \%$ - $98.48 \%$ dan recall sekitar $8.61 \%$ $96.58 \%$. Hasil algoritma ini memberikan hasil optimal daripada naive bayes baik dari segi accuracy, precision, dan recall. Hal ini dikarenakan algoritma SVM relatif mudah dan memiliki fungsi kernel yang dapat digunakan untuk mengklasifikasikan data dengan baik [35]. Adapun penelitian yang dilakukan Pulung Hendro Prastyo, dkk 
terhadap sentimen analisis berbahasa indonesia di twitter menghasilkan accuracy (96.61\%), precision (96.70), dan recall (96.58) [29].

Berikutnya text mining yang menggunakan algoritma KNN pada media sosial berbahasa Indonesia dapat menghasilkan tingkat accuracy sekitar 50\% - 98.13\%, precision $58.22 \%$ - $98 \%$ dan recall sekitar $21.05 \%$ - $98 \%$. Hasil algoritma ini memberikan hasil paling optimal yang lebih baik dibandingkan dengan naive bayes baik dari segi accuracy, precision, dan recall. Hal ini dikarenakan algoritma K-NN dapat dimaksimalkan penerapannya dengan nilai $\mathrm{k}$ yang digunakan semakin kecil maka hasil yang diberikan akan semakin akurat [3]. Adapun penelitian yang dilakukan oleh Annisa Brilani, dkk menggunakan berbagai nilai $\mathrm{k}$ pada pemrosesan text mining mengenai komentar kebencian di media sosial instagram dan ditemukan nilai $\mathrm{k}=3$ yang memberikan hasil accuracy (98.13\%), precision (98.00), dan recall (98.00) [14]. Selanjutnya, hasil dari analisis tersebut dapat disimpulkan bahwa algoritma K-NN dan SVM cocok untuk menangani berbagai kasus dan skenario text mining pada media sosial berbahasa Indonesia.

\section{KESIMPULAN}

Tiga jenis algoritma proses text mining yang diimplementasikan pada media sosial berbahasa Indonesia menghasilkan beberapa kesimpulan. Algoritma K-Nearest Neighbor (K-NN), dan Support Vector Machine (SVM) memberikan hasil optimal berdasarkan accuracy, precision dan recall. Namun, dalam satu kasus SVM masih perlu diperhatikan bahwa algoritma ini menghasilkan recall yang rendah. Selain itu, Naive Bayes menghasilkan precision, accuracy dan recall paling seimbang, namun memiliki hasil cukup tinggi.

Berdasarkan hasil tersebut bisa disebut bahwa K-NN dan SVM bisa menangani berbagai skenario dalam text mining media sosial berbahasa Indonesia dengan optimal. Namun hasil yang dikeluarkan tidak sepenuhnya menentukan salah satu algoritma lebih baik dari yang lain. Karena algoritma SVM masih mempunyai kelemahan dalam recall. Selanjutnya pada penelitian masa depan dapat dilakukan optimalisasi pada algoritma SVM, seperti dilakukan kombinasi dengan algoritma lain seperti Naive Bayes dan K-NN supaya dapat menutupi kelemahannya dalam recall.

\section{REFERENSI}

[1] Statista, "Number of internet users APAC 2021, by country Published by Statista Research Department, Mar 29, 2021 As of January 2021, China ranked first with around 939.8 million internet users while India achieved second place with 624 million internet users. China," 2021 https://www.statista.com/statistics/265153/number-of-internetusers-in-the-asia-pacific-region/ (accessed Jun. 30, 2021).

[2] P. H. Prastyo, A. S. Sumi, A. W. Dian, and A. E. Permanasari, "Tweets Responding to the Indonesian Government's Handling of COVID-19: Sentiment Analysis Using SVM with Normalized Poly Kernel," J. Inf. Syst. Eng. Bus. Intell., vol. 6, no. 2, p. 112, 2020, doi: 10.20473/jisebi.6.2.112-122.

[3] R. H. Satrio and M. A. Fauzi, "Klasifikasi Tweets Pada Twitter Menggunakan Metode K-Nearest Neighbour (K-NN) Dengan Pembobotan TF-IDF," Junral Pengemb. Teknol. Inf. dan Ilmu
Komput., vol. 3, no. 8, pp. 8293-8300, 2019

[4] M. Z. Al-Taie, S. Kadry, and J. P. Lucas, "Online Data Preprocessing: A case Study Approach," Int. J. Electr. Comput. Eng., vol. 9, no. 4, pp. 2620-2626, 2019, doi: 10.11591/ijece.v9i4.pp2620-2626.

[5] M. Kannan, S., Gurusamy, V., Vijayarani, S., Ilamathi, J. \& Nithya, "Preprocessing Techniques for Text Mining Preprocessing Techniques for Text Mining," Int. J. Comput. Sci. Commun. Networks, vol. 5, no. October 2014, pp. 7-16, 2016.

[6] R. Wongso, F. A. Luwinda, B. C. Trisnajaya, O. Rusli, and Rudy, "News Article Text Classification in Indonesian Language," Procedia Comput. Sci., vol. 116, pp. 137-143, 2017, doi: 10.1016/j.procs.2017.10.039.

[7] M. Syarifuddin, "Analisis Sentimen Opini Publik Mengenai Covid19 Pada Twitter Menggunakan Metode Naïve Bayes Dan Knn," Inti Nusa Mandiri, vol. 15, no. 1, pp. 23-28, 2020.

[8] F. S. Jumeilah, "Penerapan Support Vector Machine (SVM) untuk Pengkategorian Penelitian," J. RESTI (Rekayasa Sist. dan Teknol. Informasi), vol. 1, no. 1, pp. 19-25, 2017, doi: 10.29207/resti.vli1.11.

[9] B. Haryanto, Y. Ruldeviyani, F. Rohman, T. N. Julius Dimas, R Magdalena, and F. Muhamad Yasil, "Facebook Analysis of Community Sentiment on 2019 Indonesian Presidential Candidates From Facebook Opinion Data," Procedia Comput. Sci., vol. 161, pp. 715-722, 2019, doi: 10.1016/j.procs.2019.11.175.

[10] D. A. Agustina, S. Subanti, and E. Zukhronah, "Implementasi Tex Mining Pada Analisis Sentimen Pengguna Twitter Terhadap Marketplace di Indonesia Menggunakan Algoritma Support Vector Machine," Indones. J. Appl. Stat., vol. 3, no. 2, p. 109, 2021, doi: 10.13057/ijas.v3i2.44337.

[11] A. Taufik, "Komparasi Algoritma Text Mining Untuk Klasifikasi Review Hotel," J. Tek. Komput., vol. IV, no. 2, pp. 112-118, 2018, doi: 10.31294 /jtk.v4i2.3461.

[12] B. P. Nayoga, R. Adipradana, R. Suryadi, and D. Suhartono, "Hoax Analyzer for Indonesian News Using Deep Learning Models," Procedia Comput. Sci., vol. 179, no. 2020, pp. 704-712, 2021, doi: 10.1016/j.procs.2021.01.059.

[13] R. Umar, I. Riadi, and Purwono, "Perbandingan Metode SVM, RF dan SGD untuk Penentuan Model Klasifikasi Kinerja Programmer pada Aktivitas Media Sosial," J. RESTI (Rekayasa Sist. dan Teknol. Informasi), vol. 4, no. 2, pp. 329-335, 2020

[14] A. Briliani, B. Irawan, and C. Setianingsih, "Hate Speech Detection in Indonesian Language on Instagram Comment Section Using KNearest Neighbor Classification Method," Proc. - 2019 IEEE Int. Conf. Internet Things Intell. Syst. IoTaIS 2019, pp. 98-104, 2019 , doi: 10.1109/IoTaIS47347.2019.8980398.

[15] S. Kumar, A. K. Kar, and P. V. Ilavarasan, "Applications of Text Mining in Services Management: A Systematic Literature Review," Int. J. Inf. Manag. Data Insights, vol. 1, no. 1, p. 100008, 2021, doi: 10.1016/j.jimei.2021.100008

[16] A. D. Poernomo and S. Suharjito, "Indonesian Online Travel Agen Sentiment Analysis Using Machine Learning Methods," Indones. J. Electr. Eng. Comput. Sci., vol. 14, no. 1, p. 113, 2019, doi: 10.11591/ijeecs.v14.i1.pp113-117.

[17] N. R. Fatahillah, P. Suryati, and C. Haryawan, "Implementation of Naive Bayes classifier algorithm on social media (Twitter) to the teaching of Indonesian hate speech," Proc. - 2017 Int. Conf. Sustain. Inf. Eng. Technol. SIET 2017, vol. 2018-Janua, pp. 128 131, 2018, doi: 10.1109/SIET.2017.8304122.

[18] V. A. Fitri, R. Andreswari, and M. A. Hasibuan, "Sentiment Analysis of Social Media Twitter with Case of Anti-LGBT Campaign in Indonesia using Naïve Bayes, Decision Tree, and Random Forest Algorithm," Procedia Comput. Sci., vol. 161, pp. 765-772, 2019, doi: 10.1016/j.procs.2019.11.181.

[19] A. C. Sitepu, W. Wanayumini, and Z. Situmorang, "Determining Bullying Text Classification Using Naive Bayes Classification on Social Media," J. Varian, vol. 4, no. 2, pp. 133-140, 2021, doi: 10.30812/varian.v4i2.1086.

[20] R. C. Chairani, B. Irawan, and C. Setianingsih, "Klasifikasi Data Politik Pada Media Sosial Dengan Algoritma Naive Bayes," eProceedings Eng., vol. 8, no. 2, p. 6, 2021.

[21] D. A. Kristiyanti, A. H. Umam, M. Wahyudi, R. Amin, and L. Marlinda, "Comparison of SVM Naïve Bayes Algorithm for 
Sentiment Analysis Toward West Java Governor Candidate Period 2018-2023 Based on Public Opinion on Twitter," 2018 6th Int. Conf. Cyber IT Serv. Manag. CITSM 2018, no. Citsm, pp. 1-6, 2019, doi: 10.1109/CITSM.2018.8674352.

[22] B. Y. Pratama and R. Sarno, "Personality Classification Based on Twitter Text Using Naive Bayes, KNN and SVM," Proc. 2015 Int. Conf. Data Softw. Eng. ICODSE 2015, pp. 170-174, 2016, doi 10.1109/ICODSE. 2015.7436992.

[23] E. Barfian, B. H. Iswanto, and S. M. Isa, "Twitter Pornography Multilingual Content Identification Based on Machine Learning,' Procedia Comput. Sci., vol. 116, pp. 129-136, 2017, doi: 10.1016/j.procs.2017.10.024.

[24] N. Anggraini and M. J. Tursina, "Sentiment Analysis of School Zoning System on Youtube Social Media Using the K-Nearest Neighbor with Levenshtein Distance Algorithm," 2019 7th Int Conf. Cyber IT Serv. Manag. CITSM 2019, no. May, pp. 1-4, 2019 , doi: 10.1109/CITSM47753.2019.8965407.

[25] T. Mustaqim, K. Umam, and M. A. Muslim, "Twitter Text Mining for Sentiment Analysis on Government's Response to Forest Fires with Vader Lexicon Polarity Detection and K-Nearest Neighbor Algorithm," J. Phys. Conf. Ser., vol. 1567, no. 3, 2020, doi: 10.1088/1742-6596/1567/3/032024

[26] R. Damarta, A. Hidayat, and A. S. Abdullah, "The Application of K-Nearest Neighbors Classifier for Sentiment Analysis Of PT PLN (Persero) Twitter Account Service Quality," J. Phys. Conf. Ser. vol. 1722, no. 1, 2021, doi: 10.1088/1742-6596/1722/1/012002.

[27] F. Firmansyah et al., "Comparing Sentiment Analysis of Indonesian Presidential Election 2019 with Support Vector Machine and K-Nearest Neighbor Algorithm," 6th Int. Conf. Comput. Eng. Des., pp. 1-6, 2020, doi: 10.1109/ICCED51276.2020.9415767.

[28] S. Saifullah, Y. Fauziyah, and A. S. Aribowo, "Comparison Of Machine Learning for Sentiment Analysis in Detecting Anxiety Based on Social Media Data," J. Inform., vol. 15, no. 1, p. 45, 2021, doi: 10.26555/jifo.v15i1.a20111.

[29] P. H. Prastyo, I. Ardiyanto, and R. Hidayat, "Indonesian Sentimen Analysis: An Experimental Study of Four Kernel Functions on SVM Algorithm with TF-IDF," Int. Conf. Data Anal. Bus. Ind. W. Towar. a Sustain. Econ., pp. 1-6, 2020, doi: 10.1109/ICDABI51230.2020.9325685.

[30] M. Andriansyah et al., "Cyberbullying Comment Classification on Indonesian Selebgram Using Support Vector Machine Method," Proc. 2nd Int. Conf. Informatics Comput. ICIC 2017, vol. 2018Janua, pp. 1-5, 2018, doi: 10.1109/IAC.2017.8280617.

[31] P. G. Pratama and N. A. Rakhmawati, "Social Bot Detection on 2019 Indonesia President Candidate's Supporter's Tweets," Procedia Comput. Sci., vol. 161, pp. 813-820, 2019, doi: 10.1016/j.procs.2019.11.187.

[32] H. Syahputra, L. K. Basyar, and A. A. S. Tamba, "Setiment Analysis of Public Opinion on the Go-Jek Indonesia Through Twitter Using Algorithm Support Vector Machine," J. Phys. Conf. Ser., vol. 1462, no. 1,2020 , doi: 10.1088/17426596/1462/1/012063.

[33] W. Kaswidjanti, H. Himawan, and P. D. P. Silitonga, "The Accuracy Comparison of Social Media Sentiment Analysis Using Lexicon Based and Support Vector Machine on Souvenir Recommendations," Test Eng. Manag., vol. 82, no. 3-4, pp. 39533961, 2020.

[34] S. Bukhori et al., "Social Media Sentiment Analysis to Measure Community Response in The Millennial Road Safety Festival Program Using TF-IDF and Support Vector Machine," J. Indones. Road Saf., vol. 3, no. 2, pp. 69-82, 2020.

[35] F. Romadoni, Y. Umaidah, and B. N. Sari, “Text Mining Untuk Analisis Sentimen Pelanggan Terhadap Layanan Uang Elektronik Menggunakan Algoritma Support Vector Machine," J. Sisfokom (Sistem Inf. dan Komputer), vol. 9, no. 2, pp. 247-253, 2020, doi: 10.32736/sisfokom.v9i2.903. 